\title{
DOES DIRECT FOREIGN INVESTMENT AFFECT DOMESTIC FIRMS' CREDIT CONSTRAINTS?
}

\author{
Ann E. Harrison \\ Margaret S. McMillan \\ Working Paper 8438 \\ http://www.nber.org/papers/w8438
NATIONAL BUREAU OF ECONOMIC RESEARCH
1050 Massachusetts Avenue
Cambridge, MA 02138 \\ August 2001
}

Thanks to Eleanor Park for excellent research assistance. Thanks to Pierluigi Balduzzi for several helpful comments, and to Ray Fisman, Charlie Himmelberg, Glenn Hubbard, Dan Richards and Dani Rodrik for comments on an earlier draft. We would also like to thank seminar participants at Tufts and Columbia University, and Toni Whited for helpful comments. The views expressed herein are those of the authors and not necessarily those of the National Bureau of Economic Research.

(C) 2001 by Ann E. Harrison and Margaret S. McMillan. All rights reserved. Short sections of text, not to exceed two paragraphs, may be quoted without explicit permission provided that full credit, including (C) notice, is given to the source. 
Does Direct Foreign Investment Affect Domestic Firms' Credit Constraints?

Ann E. Harrison and Margaret S. McMillan

NBER Working Paper No. 8438

August 2001

JEL No. F2, G3

\begin{abstract}
$\underline{\text { ABSTRACT }}$
Firms in developing countries cite credit constraints as one of their primary obstacles to investment. Direct foreign investment, by bringing in scarce capital, may ease domestic firms' credit constraints. Alternatively, if foreign firms borrow heavily from domestic banks, they may exacerbate domestic firms' credit constraints by crowding them out of domestic capital markets. One plausible mechanism by which this may happen is indirect. Foreign firms may be more experienced and have better financial ratios and thus, be a safer bet for lending institutions. Using firm-level data from the Ivory Coast for the period 1974-1987 we test the following hypotheses: (1) domestic firms are more credit constrained than foreign firms and (2) borrowing by foreign firms exacerbates the credit constraints of domestic firms. Results suggest that domestic firms are significantly more credit constrained than foreign firms and that borrowing by foreign firms aggravates domestic firms' credit constraints. By splitting the sample into state-owned (SOE) and privately owned domestic enterprises we are able to show that SOEs are less financially constrained than other domestic enterprises, consistent with the notion of a "soft budget constraint". Borrowing by foreign firms affects only privately owned enterprises. Finally, we explore possible explanations for the crowding out effect.
\end{abstract}

\author{
Ann E. Harrison \\ 329 Giannini Hall \\ University of California, Berkeley \\ Berkeley, CA 94720-3310 \\ and NBER \\ harrison@are.berkeley.edu
}

\author{
Margaret S. McMillan \\ Department of Economics \\ Tufts University \\ 617-627-3137 \\ mmcmilla@tufts.edu
}


"Not all direct foreign investment around the world represents net capital flows. Often such investments are financed in local markets."

Martin Feldstein (2000)

\section{Introduction}

Firms in developing countries typically cite credit constraints as one of their primary obstacles to investment. ${ }^{1}$ It is often argued that direct foreign investment (DFI) may ease these firms' credit constraints by bringing in scarce capital. For example, domestically owned businesses in poor countries are much more likely to face credit constraints than multinational firms. ${ }^{2}$ This is one of the reasons policy makers in developing countries have eased restrictions on inward DFI and in many instances provide special incentives for DFI. Yet, if foreign firms borrow heavily from local banks, they may exacerbate domestic firms credit constraints by crowding them out of domestic capital markets. $^{3}$

In this paper, we analyze whether incoming foreign investment in developing countries plays an important role in alleviating domestic firms' credit constraints. We measure the impact of incoming direct foreign investment on domestic firms' credit constraints using firm-level data for the Ivory Coast. Specifically, we use an augmented Euler investment model to test the following hypotheses: (1) domestic firms face different credit constraints than foreign firms and (2) borrowing by foreign firms affects the credit constraints of domestic firms. We modify the standard Euler investment model by introducing a borrowing constraint and then use as proxies for the shadow value of the constraint two measures of financial distress, the debt to asset and interest coverage ratios. In

\footnotetext{
${ }^{1}$ In a recent survey of executives in 20 African countries, financing constraints were cited as a major obstacle to business expansion (Africa Competitiveness Report, 1998). In the Ivory Coast, financing constraints were ranked third out of 21; the first and second obstacles were taxation and political instability.

${ }^{2}$ In a recent survey on Kenya, the primary complaint of domestically owned businesses was credit constraints. Multinational enterprises in Kenya, however, did not cite credit constraints as a problem. Rather, they cited access to foreign exchange as their primary obstacle to doing business.

${ }^{3}$ For example, Stiglitz in an address to the Chicago Council on Foreign Relations (1998) argues that there is broad agreement about the fact that foreign direct investment brings additional capital. Feldstein (2000) argues that this is not necessarily the case. Helleiner (1989) in a survey for the Handbook of Development Economics suggests that it is unlikely that much new equity capital will result from expanded DFI flows.
} 
the absence of such constraints, these financial variables should not play a role in determining future investment. Using this framework, we also explore the differential impact of DFI on the credit constraints of state-owned enterprises (SOEs) and private domestic firms.

Apart from anecdotal and survey evidence, there is little empirical evidence on capital market imperfections and firm level investment in developing countries ${ }^{4}$. One reason for the limited empirical evidence is the difficulty in obtaining detailed firm-level data for these countries. Most of the existing evidence is difficult to interpret because these surveys are typically administered by institutions in a position to make loans such as the World Bank. Hence, firms have an incentive to report that they are credit constrained. Leading theorists, however, recognize the important role that capital market imperfections play in developing countries. ${ }^{5}$ There is also a large body of empirical evidence for developed countries that suggests that capital market imperfections play an important role in determining firm-level investment decisions. ${ }^{6}$

The results suggest that only domestic firms face credit constraints in the Ivory Coast. We also find evidence of crowding out. Specifically, we find that the share of foreign long-term borrowing at the sector level exacerbates domestic firms' credit constraints and has no effect on foreign firms' credit constraints ${ }^{7}$. When we split domestic firms into public (government-owned) and private firms, we find that public firms' investment decisions are not sensitive to debt ratios or the cost of debt. Nor is there any evidence that public firms are affected by foreign borrowing in domestic credit markets. We interpret this as evidence in support of the notion of a soft budget constraint for public firms. In contrast, private domestic firms appear more credit constrained than foreign firms and are crowded out by foreign borrowing. Finally, we find little evidence that this crowding out takes place via product markets.

\footnotetext{
${ }^{4}$ A recent exception is Love (2000), which shows that the sensitivity of investment to availability of internal funds (a proxy for financing constraints) is linked to overall financial development. Other exceptions are Tybout (1983), Harris et al. (1994), Jaramillo et al. (1996), Gelos et al. (1999), Patillo (2000), and Bigsten et al (2000).

${ }^{5}$ See for example, Aghion et al. (1999) and Banerjee and Newman (1994).

${ }^{6}$ For an excellent survey, see "Capital-Market Imperfections and Investment," by R. Glenn Hubbard, JEL, March 1998.

${ }^{7}$ In an earlier version of the paper, we included public debt as well as long-term and short-term debt. We find evidence of significant crowding out in the public debt market. Because long-term debt includes public debt, we do not include public debt in this version of the paper.
} 
Why would borrowing by foreign firms crowd out domestic firms? One plausible mechanism by which this may happen is indirect. Foreign firms may simply be more profitable and/or have access to more collateral and thus be a better investment for lending institutions ${ }^{8}$. A World Bank country economic report (1980) suggests that local banks found lending to local enterprises more costly because they were generally considered more risky. This problem was compounded by the fact that interest rates were fixed, thus creating excess demand for loans and the likelihood of credit rationing. Because of interest rate ceilings, banks could not compensate for the extra cost of lending to domestic firms and hence would prefer to lend to foreign firms ${ }^{9}$. To determine why domestic firms are more credit constrained than foreign firms, we compare the profitability of domestic and foreign firms using standard ratio analysis. Overall, foreign firms are somewhat more profitable than domestic firms. Thus, it may be that given the choice, lenders prefer to lend to foreign firms. However, when we interact relative profitability with debt ratios and interest coverage, we find little evidence that it is relative profitability that is driving our results. Instead, the share of foreign longterm borrowing remains significant. We conclude that the relative profitability of foreign firms is not driving our results.

This paper does not attempt to calculate the implications of our results for overall welfare in Cote d'Ivoire. To properly account for the total impact of DFI on the host country, we would need to take into account the impact of foreign investment on domestic wages, profits, and employment; the role of foreign investors in promoting technology transfer; and the contribution of foreign investors to tax revenues. This is beyond the scope of this paper. However, we do compute the net impact of DFI on the availability of capital, adding together the inflows from equity purchases and foreign borrowing and subtracting the local borrowing of these firms. Because the majority of DFI in Cote d'Ivoire was financed locally, DFI did not represent a large increase in net capital flows to the economy. In fact, borrowing on local credit markets by foreign firms significantly exceeded the sum of equity purchases and foreign borrowing by these firms. From that perspective, total capital available to purely domestic firms actually shrank.

\footnotetext{
${ }^{8}$ Alternatively, it may have been that foreign firms had better relationships with the bankers for any of a variety of reasons.

${ }^{9}$ This same study states that because of low domestic interest rates, foreign firms preferred to keep excess liquidity offshore. And, as a result, the government borrowed heavily abroad to capitalize local banks.
} 
Our contribution is twofold. First, we shed light on an important question in development economics: does DFI ease or exacerbate domestic firms' credit constraints? Second, this paper provides an additional test of the approaches used by Fazzari, Hubbard and Petersen (1988), Whited (1992), and Bond and Meghir (1994) to identify credit constraints. This literature relies on an observed correlation between investment and measures of internal (cash flow) or external (debt) funds, after controlling for other factors, to identify credit constraints. If there were no capital market imperfections, then a firm's financial structure should have no impact on investment. Typically, as a test of the approach, this literature selects firms which are a priori likely to be credit constrained, such as small firms, firms with high debts, or firms paying out low dividends. Researchers then examine whether these firms exhibit higher correlations between either investment and cash flow (FHP), or between investment and debt to asset ratios and interest coverage (Whited (1992)). Kaplan and Zingales (1997) have criticized this approach, arguing that firms which are identified as credit constrained by FHP are in fact not constrained, based on company statements and balance sheet evidence. $^{10}$ Our research provides additional support for both FHP and Whited (1992) by adding a new selection criterion: foreign ownership. One advantage of this approach is that ownership seems to provide a more exogenous criterion for splitting the sample than firm size or dividend policy, which has been the focus of previous studies on credit constraints. In developing countries, we would expect that firms with foreign equity participation (and hence preferential access to capital markets) should be less credit constrained, and consequently should exhibit no relationship between investment and the availability of (internal or external) funds.

The remainder of this paper is organized as follows. Section 2 outlines the general approach used for testing for credit constraints and crowding out. Section 3 describes the data. Section 4 presents results of estimation. Section 5 explores the underlying reasons for the differences between domestic and foreign firms borrowing capabilities and also presents extensions on the basic results. Section 6 discusses the implications and Section 7 concludes.

\footnotetext{
${ }^{10}$ FHP respond to this critique with a number of counter-arguments. They argue that the sample used by Kaplan and Zingales is too homogeneous to provide reliable results. FHP point out that using measures like cash stock relative to fixed investment, unused lines of credit and leverage are not reliable as indicators of relative financing constraints. They also point out that asking managers how constrained they are is not informative; in particular, company reports (relied on by Kaplan and Zingales to prove that some low dividend payout firms were not really constrained) do not indicate whether applications for loans were actually denied.
} 


\section{Testing for Credit Constraints and Crowding Out: The Framework}

A large body of literature is devoted to determining the impact of financing constraints on investment behavior. The central idea of these studies is that investment should not be determined by a firm's net worth or internal funds but only by the firm's expected future profitability. The primary means for testing this hypothesis has been to estimate investment equations including Tobin's Q (as a proxy for expected future profitability) and measures of net worth as explanatory variables. To the extent that measures of net worth predict investment behavior, researchers conclude that financing constraints are present.

We use a similar approach except that the firms in our sample are not publicly traded and hence we do not have a direct measure of Tobin's Q. Instead, we use an Euler equation approach augmented to include the possibility of borrowing constraints. This follows fairly closely the approach used by Whited (1992), Bond and Meghir (1994) and Love (2000). Using this framework, we focus on two basic questions: (1) are firms in the Ivory Coast credit constrained, and (2) does borrowing by foreign firms exacerbate the credit constraints of domestic firms. Both of these hypotheses can be nested in the same general specification. To test for the presence of credit constraints, we proxy for the shadow value of relaxing the borrowing constraint using two firm-level measures of financial distress, the debt to assets ratio (DAR) and the interest coverage ratio (COV).

The basic idea is that, in the context of the Euler equation, these indicators of financial distress should not have any impact on future investment in a world of perfect information. If, however, there are information asymmetries which restrict borrowing, then firms that are financially distressed today will be forced to substitute investment tomorrow for investment today. Hence, the model predicts a positive relationship between the shadow value of the constraint (proxied by DAR and $\mathrm{COV}$ ) and future investment. To test for a differential impact of ownership, we include interaction terms equal to our proxies for credit constraints times ownership. Finally, to test for the possibility of crowding out, we include a variable that measures the overall level of foreign borrowing by sector and a variable that measures the overall level of foreign sales by sector. The model is described below in more detail. 


\subsection{An Euler equation specification}

We estimate a version of the Euler equation, combining insights from Whited (1992), Bond and Meghir (1994), Gilchrist and Himmelberg (1998) and Love (2000). This is a relation between investment rates in successive periods, derived from dynamic optimization in the presence of symmetric, quadratic costs of adjustment. Under these assumptions, and as long as we assume that expectations are formed accordingly, the Euler equation model has the advantage of controlling for all expectational influences on the investment decision. Thus, we are not as susceptible to the criticism that financial variables are merely picking up information about expected future profitability of the firm.

The theoretical framework is very similar to Bond and Meghir (1994), except that we explicitly introduce a borrowing constraint in the framework, along the same lines as Whited (1992) and Love (2000). One potential criticism of Bond and Meghir (1994) is that they interpret rejection of their model as an indicator of credit constraints. Although this interpretation is quite plausible, the advantage of explicitly including credit constraints in the initial formulation is that it is no longer necessary to reject the model in order to find evidence of credit constraints, nor is it necessary to assume that rejection of the model implies the presence of credit constraints. The other advantage of our approach is that since the coefficient on cash flow is no longer the critical variable of interest for identifying credit constraints, the possibility that cash flow proxies for unobserved profit opportunities no longer poses a critical estimation problem.

The firm is assumed to maximize the present discounted value of current and future net cash flows. The firm borrows at time $\mathrm{t}$ an amount given by $\mathrm{B}_{\mathrm{it}}$, and pays interest on the debt given by $\mathrm{i}_{\mathrm{it}}$. Inflation is denoted by $\pi_{\mathrm{it}}$. The credit constraint is modeled as a ceiling on borrowing, denoted by $\mathrm{B}_{\mathrm{it}}{ }^{*}$. If we had introduced a financing constraint by imposing a non-negative dividend condition, as in Whited (1992) and Love (2000), the empirical specification would have looked very similar (if not identical). Letting $L_{i t}$ denote variable factor inputs, $w_{i t}$ the price of variable factors $p_{i t}^{I}$ the price of the investment good, $p_{i t}$ the price of output, $\beta_{t+j}^{t}$ the nominal discount factor between period t and period $\mathrm{t}+\mathrm{j}, \delta$ the rate of depreciation, $F\left(K_{i t}, L_{i t}\right)$ the production function gross of adjustment costs, $G\left(I_{i t}, K_{i t}\right)$ 
the adjustment cost function and $E_{t}($.$) the expectations operator conditional on information available$ in period $t$, the firm solves

$$
\begin{gathered}
\max _{t}\left[\sum_{j=0}^{\infty} \beta_{t+j}^{t} R\left(K_{i, t+j}, L_{i, t+j}, I_{i, t+j}\right)\right] \\
\text { s.t. } K_{i t}=(1-\delta) K_{i, t-1}+I_{i t} \text { and } \\
B_{i t} \leq B_{i t} *
\end{gathered}
$$

where $\mathrm{R}_{\mathrm{it}}=\mathrm{p}_{\mathrm{it}} \mathrm{F}\left(\mathrm{K}_{\mathrm{it}}, \mathrm{L}_{\mathrm{it}}\right)-\mathrm{p}_{\mathrm{it}} \mathrm{G}\left(\mathrm{I}_{\mathrm{it}}, \mathrm{K}_{\mathrm{it}}\right)-\mathrm{w}_{\mathrm{it}} \mathrm{L}_{\mathrm{it}}-\mathrm{p}_{\mathrm{it}}^{\mathrm{I}} \mathrm{I}_{\mathrm{it}}-\mathrm{i}_{\mathrm{t}-1} \mathrm{~B}_{\mathrm{i}, \mathrm{t}-1}+\mathrm{B}_{\mathrm{it}}-\left(1-\pi_{\mathrm{t}-1}\right) \mathrm{B}_{\mathrm{i}, \mathrm{t}-1}$.

The Euler equation characterizing the optimal investment path relates marginal adjustment costs in adjacent periods. This can be written as,

$$
(1-\delta)\left(1-\gamma_{i t}\right) \beta_{t+1}^{t} E_{t}\left(\frac{\partial R}{\partial I}\right)_{i, t+1}=\left(\frac{\partial R}{\partial I}\right)_{i t}+\left(\frac{\partial R}{\partial K}\right)_{i t} .
$$

The right-hand side of equation (2) represents the marginal cost of investment today net of the marginal increase in output (because investment is assumed to be immediately productive). The lefthand side of equation (2) represents the present value of the marginal adjustment cost of investing tomorrow. Note that because investment is immediately productive, postponing the investment decision involves no future loss in output. The value $\gamma_{i t}$ represents the multiplier associated with the borrowing constraint. Compared to an unconstrained firm, the firm facing a binding liquidity constraint has a higher value of $\gamma_{\text {it }}$ and thus incurs a higher marginal cost of investment today. Thus, the constrained firm behaves as if it has a higher discount rate and for a given level of adjustment 
costs today, will require a higher rate of return on investment today relative to investment tomorrow. Ceteris paribus, constrained firms will intertemporally substitute investment today for investment tomorrow.

The major challenge is to find empirical proxies for the derivative of net revenue $\mathrm{R}$ with respect to $\mathrm{I}$ and $\mathrm{K}$, as well as to find proxies for $\gamma$. If we specify the adjustment cost function as $G$ $\left(I_{i t}, K_{i t}\right)=(b / 2) *\left[(I / K)_{i t}-c\right]^{2} K_{i t}$, which is linearly homogenous in investment and capital, Bond and Meghir (1994) show that the derivatives of net revenue with respect to I and K can be written as:

$$
\begin{aligned}
& \left(\frac{\partial R}{\partial I}\right)_{t}=-b \alpha p_{t}\left(\frac{I}{K}\right)_{t}+b c \alpha p_{t}-p_{t}^{I} \\
& \left(\frac{\partial R}{\partial K}\right)_{t}=\alpha p_{t}\left(\frac{Y}{K}\right)_{t}-\alpha p_{t}\left(\frac{\partial F}{\partial L} \frac{L}{K}\right)_{t}+b \alpha p_{t}\left(\frac{I}{K}\right)_{t}^{2}-b c \alpha p_{t}\left(\frac{I}{K}\right)_{t}
\end{aligned}
$$

where, $Y=F-G$ denotes net output and $\alpha=1-(1 / \varepsilon)>0$. We allow for imperfect competition but the price elasticity of demand $(\varepsilon>0)$ is assumed to be constant. $\mathrm{Y}$ is assumed to be linearly homogeneous in $\mathrm{K}$ and $\mathrm{L}$.

If we begin by assuming that there are no credit constraints $(\gamma=0)$, then combining (3a) and (3b) above, and adding the subscript $\mathrm{j}$ to denote sector, yields the following estimating equation:

$$
\begin{aligned}
& \left(\frac{\mathrm{I}}{\mathrm{K}}\right)_{\mathrm{ij}, \mathrm{t}+1}=\beta_{1}\left(\frac{\mathrm{I}}{\mathrm{K}}\right)_{\mathrm{ijt}}-\beta_{2}\left(\frac{\mathrm{I}}{\mathrm{K}}\right)_{\mathrm{ijt}}^{2}-\beta_{3}\left(\frac{\mathrm{C}}{\mathrm{K}}\right)_{\mathrm{ijt}}+\beta_{4} \mathrm{U}_{\mathrm{ijt}}+\beta_{5}\left(\frac{\mathrm{Y}}{\mathrm{K}}\right)_{\mathrm{ijt}}+\mathrm{s}_{\mathrm{j} t}+\mathrm{v}_{\mathrm{ij}, \mathrm{t}+1} \cdot \\
& \text { where } \mathrm{C}_{\mathrm{ijt}}=\mathrm{p}_{\mathrm{ijt}} \mathrm{F}\left(\mathrm{K}_{\mathrm{ijt}}, \mathrm{L}_{\mathrm{ijt}}\right)-\mathrm{p}_{\mathrm{ijt}} \mathrm{G}\left(\mathrm{I}_{\mathrm{ijt}}, \mathrm{K}_{\mathrm{ijt}}\right)-\mathrm{w}_{\mathrm{ijt}} \mathrm{L}_{\mathrm{ijt}}
\end{aligned}
$$

is real cash flow and $U_{i j t}$ is the real user cost of capital. Expected future investment (proxied by actual future investment) is positively related to current investment and negatively related to the square of current investment. Future investment is negatively related to current cash flow and the 
user cost of capital. Under imperfect competition, future investment is positively related to current $(\mathrm{Y} / \mathrm{K})$. We also include sector-specific effects.

The negative association between current cash flow and future investment is explained in the following way. A high level of current cash flow implies lower net marginal adjustment costs today. Because in equilibrium, marginal adjustment costs are equated across periods in expectation, this implies lower expected marginal adjustment costs and hence lower expected investment tomorrow.

\subsection{Testing for Credit Constraints and Crowding Out using the Euler Specification}

We need to modify the basic specification in (4) to test for credit constraints. As is evident from the first order condition (2), we need to find empirical proxies for $\gamma$. If we linearize (using a Taylor expansion) the product of $(1-\gamma)$ and next period's derivative of net revenue with respect to investment, then we can take $\gamma$ to the right-hand side of (4). We will empirically proxy for $\gamma$ with two firm-level measures of financial distress: the ratio of total debt to assets (DAR), and a measure of interest coverage (COV) which is defined as interest payments divided by debt. In a world with no credit constraints, these measures should have no impact on investment since all that matters is the expected future profitability of investment. In a credit constrained world, these two measures will be positively related to future investment. Firms that are financially distressed are more likely to be up against their borrowing constraints and are hence more likely to postpone investment until tomorrow.

Following Whited (1992), DAR is the ratio of the market value of the firm's debt to the value of the firm's fixed assets. Thus, DAR can be interpreted both as a measure of a firm's lack of collateral and as a measure of a firm's current demand for borrowing relative to it's capacity to borrow. The interest coverage ratio, $\mathrm{COV}$, is defined as the ratio of the firm's interest expense to the sum of the firm's interest expense plus cash flow. A higher value of COV today means that a firm is exhausting relatively more resources on servicing it's debt and is likely to be closer to it's debt capacity. 
To test whether foreign presence in sector $\mathrm{j}$ and year $\mathrm{t}$ alters domestic firms' credit constraints, we interact these firm-level variables with the share of foreign borrowing in sector $\mathrm{j}$ and year $\mathrm{t}$. This yields the following empirical proxy for $\gamma$ :

$$
\begin{aligned}
\gamma= & \beta_{5} \mathrm{DAR}_{\mathrm{ijt}}+\beta_{6} \mathrm{COV}_{\mathrm{ijt}} \\
& +\beta_{7} \mathrm{DAR}_{\mathrm{ijt}} * \mathrm{FDEBT}_{-} \text {Sector }_{\mathrm{jt}}+\beta_{8} \mathrm{COV}_{\mathrm{ijt}} * \mathrm{FDEBT}_{-} \text {Sector }_{\mathrm{jt}} \\
& +\beta_{9} * \mathrm{FDEBT}_{-} \text {Sector }_{\mathrm{jt}}
\end{aligned}
$$

The coefficients on $D A R$ and $C O V$ are expected to be positive and significant if the firm is credit constrained. The coefficients $\beta_{7}$ and $\beta_{8}$ are expected to be positive and significant if foreign borrowing in the sector $\left(F D E B T\right.$ Sector $\left.{ }_{j t}\right)$ exacerbates credit constraints for the individual firms in the sector. This interaction term is meant to capture "credit rationing" by lenders. We interpret the coefficients on the interaction of our DAR and COV variables with foreign debt as an indicator of crowding out.

$F D E B T \_S_{\text {Sector }}$ is a measure of the level of foreign borrowing in sector $\mathrm{j}$ at time $\mathrm{t}$. If the level of foreign borrowing in sector $\mathrm{j}$ crowds out domestic borrowing in sector $\mathrm{j}$ at time $\mathrm{t}$, then the coefficients $\beta_{7}$ and $\beta_{8}$ should be positive. One potential area of concern is that foreign firms' share of the debt market is really capturing the negative impact of foreign entry on domestic market share, and consequently on the level of investment. To control for that possibility, we also test the following modified equation: 


$$
\begin{aligned}
\gamma= & \beta_{5} D A R_{i j t}+\beta_{6} C O V_{i j t} \\
& +\beta_{7} D A R_{i j t} * F D E B T_{-} \text {Sector }_{j t}+\beta_{8} C O V_{i j t} * F D E B T_{-} \text {Sector }_{j t} \\
& +\beta_{9} * F D E B T_{-} \text {Sector }_{j t} \\
& +\beta_{10} D A R_{i j t} * F S A L E_{-} \text {Sector }_{j t}+\beta_{11} \text { COV }_{i j t} * F S A L E \_ \text {Sector }_{j t} \\
& +\beta_{12} * F S A L E_{-} \text {Sector }_{j t}
\end{aligned}
$$

FSALE_Sector $j$ is a measure of the level of foreign sales in sector $\mathrm{j}$ at time $\mathrm{t}$. If the level of foreign sales in sector $\mathrm{j}$ makes domestic firms less profitable and therefore less able to borrow in sector $\mathrm{j}$ at time $\mathrm{t}$, then the coefficients $\beta_{10}$ and $\beta_{11}$ should be positive. Equation (6) consequently is a robustness check on our crowding out hypothesis via financial markets. If, instead, domestic firms are crowded out of local markets due to product market competition, then adding these additional terms should reduce or eliminate the significance of crowding out in the financial sector.

\subsection{Estimation Issues}

A number of issues come up in estimation. First, the user cost of capital is typically unobservable. Most researchers, including Bond and Meghir (1994), proxy for the user cost of capital using firm dummies. We do the same thing, but we also estimate our equation by using as a proxy for the user cost of capital, the coefficient of variation of real profits relative to other firms in the same industry. Our choice of proxy for the user cost of capital is based on recent work by Minton and Schrand (JFE, 99) who find that cash flow volatility is generally associated with lower average levels of investment and a higher cost of accessing external capital. Since one possible critique of this approach is that the user cost of capital only accounts for one component of differences across firms (which are fixed over time), we focus on our fixed-effect results and do not report the alternative specification here. 
Second, our model is restrictive in the sense that we would expect domestically owned and foreign owned enterprises to exhibit both different degrees of credit constraints as well as different sensitivities to foreign entry. To allow for a differential degree of constraints, we introduce the variable DFI_Firm, which is the share of foreign equity participation at the plant level, varying between 0 and 100 percent. What this means is that we will allow all the coefficients in equations (4), (5) and (6) to vary with the degree of foreign ownership. We will also allow for an independent effect of foreign ownership in a plant on investment. If foreign ownership increases the overall level of investment, we should observe a positive coefficient on DFI_Firm $i j t$. If foreign firms are less credit constrained (or not constrained at all) than domestic firms then the sign of the coefficient on the interactions between DAR and COV and DFI_Firm should be negative (or zero).

Our final estimating equation is thus:

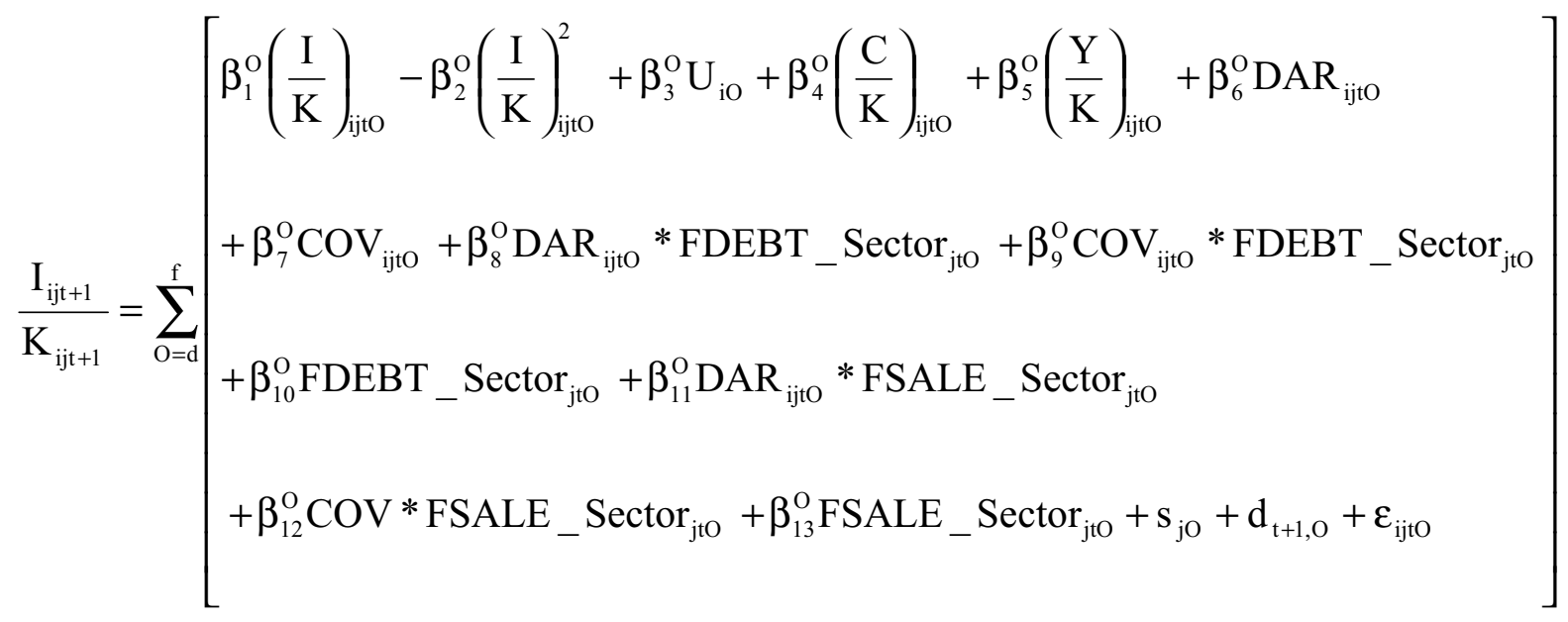

Where $\mathrm{O}$ stands for ownership, $\mathrm{d}$ is domestic and $\mathrm{f}$ is foreign. Firms with more than an average of $49 \%$ foreign ownership over the sample period are considered foreign, otherwise, they are domestic. We also include sector dummies, $s$, and time dummies, $d$.

Results of estimating equation (7) are presented in Tables 2 through 4 at the end of the paper. Table 2 includes all firms, Table 3 splits the sample of domestic firms into state-owned enterprises 
and private enterprises and Table 4 explores the possibility that it might be the relative size and/or better performance of foreign firms that is driving our results.

\section{Data}

The firm data are taken from the Banque de Donnees Financieres (BdDF), which is instructed to gather annual information on all industrial firms in the Ivory Coast. The number of firms in individual years ranges from around 250 in the 1970 s to nearly 500 in the mid-1980s. Although the coverage of the industrial sector is incomplete (informal enterprises are excluded and small formal firms are under-represented), the BdDF covers almost all large and medium-sized formal manufacturing enterprises. From this sample, we deleted a number of observations where firms reported zero or negative sales, employees, and/or material inputs. This left us with a sample of 399 firms over the period 1974-1987.

We estimate equation (7) using our panel of 399 Ivorian firms during the period 1974-1987. These estimates require data on real output, capital stock, labor costs, material costs, investment, borrowing and ownership shares. We do not use reported profits instead we compute operating cash flow as total sales less the cost of labor, material inputs and taxes. The value of the real capital stock was constructed using the perpetual inventory method. All variables were deflated by two-digit sectoral level price deflators to obtain real values. Table A.4 reports summary statistics for the 399 firms in our sample.

Our measure of foreign borrowing at the sectoral level is defined as:

$$
F D E B T_{-} \text {Sector }_{j t}=\frac{\sum_{i} D E B T_{i j t} * D F I_{-} \text {Firm }_{i j t}}{\sum_{i} D E B T_{i j t}}
$$

Our measure of foreign sales at the sectoral level is defined as: 


$$
F S A L E_{-} \text {Sector }_{j t}=\frac{\sum_{i} \text { REAL SALES }_{i j t} * \text { DFI_Firm }}{i j t}
$$

Our justification for using sector level variables derives from the fact that in order to mitigate portfolio risk, banks frequently diversify according to sector ${ }^{11}$. As an illustration, one 1995 publication which discusses bank risk management explains that "diversification means avoiding concentration in a single company, industry group or geographic area" [italics added for emphasis]. We also have evidence that in 1976 banks in the Ivory Coast were assigned sectoral limits by the Banque Centrale des Etats de L'Afrique de L'Ouest (World Bank, 1978) ${ }^{12}$.

The importance of foreign equity participation during the period 1974 to 1987 is significant and variable by sector (see Table A.2). The share of foreign equity was particularly high in the leather industry $(93.12 \%)$ while in other sectors such as coffee it was less important $(52.44 \%)$. Domestic participation is split between private and SOEs with private domestic firms taking the lead in coffee (44.69\%) and domestic SOEs taking the lead in cooking oils (32.63\%). In addition to cross-section variation, there were also substantial changes in the share of foreign ownership over the sample period.

Although variable, foreign participation in the Ivorian economy remained substantial throughout the period we study. Table A.5 indicates that as a share of total reported sales in the economy foreign firms accounted for $83.15 \%$ in 1975 and $70.10 \%$ in 1987 . The importance of borrowing by foreign firms is a slightly trickier issue since it is likely that foreign firms have access to funds overseas while domestic firms may not. Table A.5 indicates that as a share of total credit in the economy foreign firms accounted for $76.32 \%$ in 1975 and $60.89 \%$ in 1987 . This probably overstates somewhat the extent to which foreign firms relied on local bank financing as opposed to

\footnotetext{
${ }^{11}$ Chapter 10 in Active Bank Risk Management: enhancing investment \& credit portfolio performance, 1995.

12 The majority of manufacturing activity was located in Abidjan and thus it would have been impossible to diversify on a regional basis (World Bank, 1978).
} 
other sources of financing. Nevertheless, data for 1985 (Table A.1) indicate that on average only $8 \%$ of foreign firms' long-term funds came from overseas. Thus, a substantial portion of borrowing by foreign firms was done locally.

The number of firms in each sector and the distribution of ownership are provided in Table A.2. For purposes of presentation, we aggregate up to the 2-digit SIC level or nine sectors: food processing, textiles \& apparel, leather products, wood products, chemicals, rubber \& cement, building materials, tools \& transportation materials, and paper products. Our analysis defines sector at the four-digit level.

\section{Investment Equation Estimates}

The standard solution to measuring the user cost of capital is to assume that it can be captured by a firm fixed effect, which we already allow for in equation (7). Our approach to accounting for firm-fixed effects is to sweep out the fixed effects by taking deviation from firm means. However, this could induce bias in the lagged dependent variable which is one of the independent variables in equation (7). One solution to this problem is to account for the potential firm fixed effect by taking a within transformation, and then applying instrumental variables (IV) estimation or Generalized Method of Moments (GMM) estimation. Our approach is to sweep out the firm fixed effect by taking a Helmert transformation of equation (5), and then estimate the transformed equation using $\mathrm{GMM}^{13}$.

Table 1 reports the results from estimating equation 7. The basic specification is reported in column (1). We allow the coefficients to vary across foreign-owned and domestically-owned firms. As indicated earlier, a foreign firm is defined as one for which more than 49 percent of the equity is owned by foreigners. The basic specification does not include debt or interest coverage. The restrictions imposed by the model are generally accepted: the coefficient on lagged investment is positive, the coefficient on squared (lagged) investment is negative, the coefficient on $\mathrm{Y} / \mathrm{K}$ is positive and the coefficient on cash flow is negative. Since we have more instruments than exogenous variables, we have a number of overidentifying restrictions in each regression. Hansen's J statistic,

\footnotetext{
${ }^{13}$ The Helmert transformation involves taking deviations from future means (see Arellano \& Bover ('91) for details). This procedure leaves the untransformed variables orthogonal to the transformed error term for period t- 1 and greater. Hence, we use as instruments, levels of the variables dated t-1 and earlier.
} 
reported in Table 1, is distributed as a chi-square and indicates whether the overidentifying restrictions of the model are accepted. In every case, the overidentifying restrictions are accepted.

Column (2) introduces the two proxies for credit constraints, the ratio of lagged debt to assets (DAR), and the lagged interest coverage ratio (COV). The coefficients on DAR and COV are significant and positive for domestic firms, equal to .103 and .004 respectively. For foreign firms, however, those coefficients, at .011 (for DEBT) and .001 (for COV) are close to zero in magnitude and insignificant. This suggests that domestic firms are credit constrained, while foreign enterprises are not.The addition of DEBT and COV substantially improves the fit of the model, as indicated by the fall in the value of the Hansen J Statistic.

Column (3) tests for crowding out in the financial sector. As in column (2), we allow the coefficients on the independent variables to vary across foreign and domestic enterprises. The coefficient on the interaction of DAR and COV and the share of foreign borrowing at the sector level indicates the extent of crowding out. The results in column (3) indicate that foreign firms crowd out domestic firms. The coefficient on DAR and COV interacted with sectoral foreign share of total borrowing is positive and statistically significant. The coefficient on DAR alone is half the magnitude in column (1), confirming that a large part of the credit constraints identified in column (1) are due to foreign entry. The results in column (3) also indicate that there is no crowding out of foreign firms: DAR and COV interacted with sectoral foreign share of borrowing is not significant.

One possible explanation for the observed correlation between DAR (or COV) and foreign sector share of total borrowing and investment could be the following: domestic firms face greater domestic competition with foreign entry. Increased competition-which could be correlated with the foreign share in domestic borrowing--leads to both lower investment and a decline in profits, which are correlated with cash flow. We test for this possibility in column (4). We add two additional terms, DAR*Share Foreign Sales and COV*Share Foreign Sales to the basic specification. Share Foreign Sales is defined as the share of foreign-owned firms in total sales in a particular sector and year. If foreign borrowing is simply a proxy for competition, then the crowding out variables should become statistically insignificant. The results in column (4) suggest that this is not the case. The coefficients on DAR and COV interacted with foreign borrowing remain the same in magnitude and 
are statistically significant. The coefficients on Share Foreign Sales and Share Foreign Sales interacted with DAR and COV are insignificant, suggesting that these are not significant factors in affecting domestic or foreign investment.

In a number of African countries, SOEs play a major role in all aspects of the economy, including manufacturing. Cote d'Ivoire is no exception. Appendix Table A.2 shows that SOEs account for a large share of sales in a number of sectors, such as food products, rubber and cement. Yet, SOEs are likely to face a very different set of credit constraints than their private sector counterparts. Bertero and Rondi (2000) indicate that the cash flow-investment correlation could differ from private sector firms for a number of reasons. To the extent that SOEs benefit from a soft budget constraint, they may be less credit constrained than private enterprises. This would indicate a weaker link (or no link at all) between investment and cash flow. On the other hand, an argument could also be made that the link between cash flow and investment is likely to be stronger for public enterprises. Bertero and Rondi (2000) argue that agency problems are more severe in public enterprises. To the extent that managers of SOEs are more likely to pursue private objectives, they may wish to over invest relative to the optimum. This may lead us to find a stronger link between cash flow and investment for this set of firms.

Table 2 redoes the specification reported in Table 1, but allows coefficients to vary across public and private enterprises. In Table 2, column (1) reports the basic specification. Although the coefficients on investment and lagged investment are significantly different in magnitudes, for both the private enterprises and the SOEs the signs are as expected. Column (2) introduces DAR and COV. While the coefficients on DAR and COV remain significant and positive for domestically owned private enterprises, the coefficients on both measures of credit constraints are insignificant for the SOEs. The coefficients on DAR and COV remain statistically insignificant in columns (2) and (3), suggesting that SOEs are not credit constrained. These results are consistent with the perception that SOEs, due to their access to soft loans or government support, are less likely to be credit constrained than private sector enterprises. Columns (3) and (4) test for crowding out by foreign firms. Across all specifications, the results suggest that SOEs are unaffected by foreign investors. These results are unaffected by adding DAR and COV interacted with the share of foreign sales. 
There appears to be fairly robust evidence of crowding out of domestic firms by foreign firms. The interaction between our debt and interest coverage measures with the level of foreign borrowing at the sector level is positive and significant across all specifications. Finally, the results suggest that crowding out only affects domestically owned, private enterprises. Neither SOEs nor other foreign enterprises are crowded out by foreign entry in their sector.

\section{Extensions}

Results of our analysis suggest that only domestic firms are credit constrained and that foreign firms crowd out domestic firms in local capital markets. Both (1) as a test of the Euler equation approach and (2) to allow us to gain insights into why foreign firms are crowding out domestic firms, we report quantitative measures of operational and financial health in Table 3 . If the Euler equation approach accurately measures the extent of credit constraints, then we would expect that foreign firms would appear to be less constrained using quantitative ratios such as cash flow to investment and debt to capital. We also report different measures of profitability across the two sets of firms. Foreign firms may crowd out domestic firms on local credit markets simply because they are more profitable. We are particularly interested in identifying whether foreign firms crowd out domestic firms, after controlling for the same level of profitability, a possibility we will explore later in this section. Such a result would suggest that crowding out may not be an efficient outcome; there may be a "bias" in favor of allocating credit to foreigners.

\subsection{Financial Ratio Analysis}

\section{Economic and Debt Ratios}

The results in Panels A and B of Table 3 suggest that, using a wide range of indicators, domestic firms are more credit constrained. The means show that investment relative to capital is significantly lower for domestic relative to foreign firms. Although cash flow levels are similar for private domestic and foreign firms, sales growth is slightly lower. The next set of ratios in Table 3 are 
leverage ratios. Overall, the debt to assets ratio is about the same for private domestic and foreign firms, but significantly higher for SOEs. The interest coverage ratio (COV) is significantly higher for private firms relative to foreign enterprises, indicating that they face higher borrowing costs. Real debt growth is significantly lower for private domestic enterprises compared to SOEs and foreign enterprises. These results are consistent with the earlier regression results showing that domestic firms are more financially constrained than both foreign enterprises and SOEs.

\section{Profitability Ratios}

The next set of ratios in Table 3 measure profitability. Using three different measures of profitability, firms with foreign assets are significantly more profitable than private domestic enterprises. Return on assets and asset turnover indicate how intensely the firm's assets are being put to use. The substantially higher ratios for foreign as compared to domestic firms indicate that foreign firms are indeed more profitable. In addition, the return on assets and asset turnover differences suggest that foreign firms are operating at or close to capacity and it may prove difficult to generate further business without additional investment.

\section{Firm Size}

The last set of ratios in Table 3 measure firm size. One possible critique of our results is that they simply reflect the fact that foreign enterprises are larger than domestic enterprises, and therefore more profitable and less credit constrained. The means reflecting differences in firm size suggest that this may be the case. Using sales or employee measures of firm size, the results indicate that private domestic enterprises are significantly smaller than foreign firms. Again, the means highlight the importance of separating SOEs than other domestic enterprises. SOEs are significantly larger than either foreign or private domestic enterprises, and also more profitable than their private sector counterparts. 


\subsection{Does firm size or higher profitability explain the impact of foreign investment?}

If foreign firms are significantly larger than domestically owned enterprises, then domestic firms may be crowded out due to size rather than ownership issues. There is a vast literature documenting that smaller enterprises are discriminated against on credit markets relative to large firms. Table 4 lists the baseline specification from Table 2, then adds sector-level controls for relative profitability of foreign versus domestic (private only) enterprises. In columns (2) and (3), we add the interaction of DAR and COV with different measures of foreign relative to domestic firm size. The results indicate that size is not driving the results. The coefficients on DAR and COV interacted with the share of foreign borrowing remain significant and positive.

The profitability ratios in Table 3 highlight the possibility that foreign firms may crowd out domestic enterprises because they are simply more profitable. We test for whether crowding out occurs as a result of the superior profitability of foreign firms by adding the interaction of DAR and COV with the sector-level relative profitability of foreign enterprises. We measure the profitability of foreign firms relative to the profitability of domestic firms by taking the ratio of the measure of the profitability of the foreign firm to the measure of profitability for the domestic firm. For example, we calculate the relative profit margin of foreign firms in the following way:

$$
\text { RELPROF_Sector }_{\mathrm{jt}}=\frac{\frac{\sum_{\mathrm{i}} \operatorname{REALPROFITS}_{\mathrm{ijt}} * \mathrm{DFI}_{-} \text {Firm }_{\mathrm{ijt}}}{\sum_{\mathrm{i}} \operatorname{REALSALES}_{\mathrm{ijt}} * \mathrm{DFI}_{-} \text {Firm }_{\mathrm{ijt}}}}{\frac{\sum_{\mathrm{i}} \operatorname{REALPROFITS}_{\mathrm{ijt}} *\left(1-\mathrm{DFI}_{-} \text {Firm }_{\mathrm{ijt}}\right)}{\sum_{\mathrm{i}} \operatorname{REALSALES}_{\mathrm{ijt}} *\left(1-\mathrm{DFI} \text { Firm }_{\mathrm{ijt}}\right)}}
$$


The addition of this interaction term does not affect our earlier results, indicating that relative profitability is not driving the results on crowding out. We also performed similar tests defining profitability as the relative return on assets or relative asset turnover, but since the results were unaffected they are not reported here. We conclude that relative profitability may matter, but it is not driving our results on crowding out of domestic firms by foreign enterprises.

\subsection{OLS Estimates}

Although we do not report them here, we also estimated Tables 1, 2, and 4 using ordinary least squares. In that specification, we control for firm-specific differences in investment with our measure of the user cost capital, which is defined as the coefficient of variation on real profits relative to other firms in the sector. Those results show that the user cost of capital negatively affects investment for foreign enterprises but has no impact on domestic firms. Foreign firms respond more to higher capital costs, which are proxied here with the coefficient of variation on real profits. These results are consistent with unreported results showing that there are time invariant differences across foreign enterprises (captured here by the user cost of capital term) but not across domestic enterprises. The OLS estimates are consistent with the GMM estimates: domestic firms appear to be credit constrained, but foreign enterprises and SOEs are not. Domestic enterprises are more credit constrained in sectors where foreign borrowing accounts for a higher share of sectoral borrowing.

\section{$5.4 \quad$ Other Sample Splits}

Finally, in Tables A.6 and A.7 we report estimates of our Euler equations using other sample splits, such as firm size and profitability. Table A.6 reports the Euler equations within the inclusion of measures of credit constraints, while Table A.7 adds credit constraints. The results in Table A.6 suggest that even without the addition of terms which capture the importance of credit constraints, the overidentifying restrictions are not rejected for the sample. However, for domestic enterprises, the fit improves considerably with the addition of DAR and COV. 
The results in Tables A.7 highlight the significance of ownership in Cote d'Ivoire. There are no differences in credit constraints faced by small versus large firms, or low versus high profitability firms. The critical difference is ownership. Table A.7 highlights that ownership is the critical characteristic in explaining differences in credit constraints in Cote d'Ivoire.

\section{Policy Implications}

To properly account for the total impact of DFI on the host country, we would need to take into account the impact of foreign investment on domestic wages, profits, and employment; the role of foreign investors in promoting technology transfer; and the contribution of foreign investors to tax revenues. This is not addressed in this paper. However, we do compute the net impact of DFI on the availability of capital, adding together the inflows from equity purchases and foreign borrowing and subtracting the local borrowing of these firms.

The fact that foreign firms borrowed locally does not necessarily mean that the net impact of DFI on capital flows was negative. We also must consider the fact that foreign firms brought in equity. Table 5 shows the total amount borrowed by foreign firms and the total amount of equity brought in by foreign firms. In all years, the amount borrowed domestically substantially exceeds the equity contribution of foreign firms. Note that these figures do not properly measure the impact of foreign investment on net capital flows, as they do not account for repatriated profits and workers remittances. Table 5 indicates that because the majority of DFI was financed locally, DFI did not represent a significant increase in net capital flows to the economy. In fact, borrowing on local credit markets by foreign firms significantly exceeded the sum of equity purchases and foreign borrowing by these firms. To the extent that joint ventures are not considered local firms, the results suggest that the total amount of funds available to purely domestically owned firms actually shrank with the increase in foreign investment.

These negatives must be balanced against potential positives in order to obtain a complete picture of the welfare implications of the DFI. Beneficial effects of DFI include technology transfer, employee training and higher wages, and tax revenues. Table 5 indicates that foreign firms did contribute a significant amount to total tax revenues. This is the focus of research elsewhere 
(Branstetter and Feenstra (1999)). Branstetter and Feenstra analyze the welfare gains from the inflow of foreign investment into China, calculating the implied weights in the social welfare function. However, they do not address the possibility that foreign investors could affect local credit markets, possibly crowding out domestic firms.

This issue is an important one because one major reason cited in policy discussions for why foreign firms should be encouraged to relocate in one's home country is that these foreign firms bring in scarce capital. Our results suggest that policy makers should be more careful about assuming that direct foreign investment expands the availability of credit for domestic investors. The extreme case would be a foreign investor who sets up a foreign firm in the host country and finances 100 percent of his or her investment from local credit markets. To the extent that foreign investors may present more profitable investment opportunities, local banks may be applauded for awarding them a higher percentage of loans. Yet our results suggest that the crowding out of local firms by foreign investors largely cannot be explained by differences in profitability. In summary, our results suggest that the expected benefits from foreign investors in terms of jobs, technology transfer, and competition must be weighed against the potential cost of greater credit constraints on domestic firms.

\section{Conclusion}

In this paper, we attempt to answer a question, which has not been addressed elsewhere: does the entry of foreign enterprises in developing country credit markets hurt their domestic competitors? Although foreign investment conveys benefits by bringing in scarce capital, those benefits may be mitigated if foreign enterprises crowd out domestic enterprises in the local credit markets. Our results suggest a difference between the credit constraints faced by domestic and foreign firms. In addition, we find that one major reason why domestic enterprises are more credit constrained than their foreign counterparts in the same sector is due to crowding out by foreign entrants. Further, we find that one contributing factor is that foreign firms are more profitable and more liquid. Hence, foreign firms might be a better investment for local banks than domestic firms. Nevertheless, our results remain even after we control for the higher profitability of foreign enterprises. In other words, even after controlling for the profitability of foreign firms, domestic enterprises are still "crowded out" by their foreign competitors. 
We also examine the performance of state-owned enterprises (SOEs) relative to their private sector counterparts. For SOEs, debt to asset measures and interest coverage do not significantly affect investment, indicating that SOEs are not credit constrained. Nor is there any evidence that they are affected by foreign borrowing on domestic credit markets. These results suggest that SOEs are not credit constrained, perhaps because during this period they could be characterized by being subject to a soft budget constraint. In addition, SOEs are not crowded out by foreign enterprises of domestic credit markets, in contrast to their private sector counterparts.

We explore whether our results on crowding out could be due to unobserved factors, such as increased competition from foreign enterprises or differences in firms' size. Our results suggest that this is not the case. Although the Ivory Coast may be an unusual case, our empirical results suggest that policy makers should be cautious in assuming that foreign investors expand credit opportunities for domestic enterprises. In the Ivory Coast, foreign investors certainly eased credit constraints for firms with foreign investment, but firms which did not receive foreign investment became more credit constrained. In part, these results are driven by the fact that foreign investors borrowed heavily on local credit markets, where interest rates were set artificially low. 


\section{References}

Aghion, Phillipe, Eve Caroli and Cecilia Garcia-Penalosa, Inequality and Economic Growth:The Perspective of the New Growth Theories, Journal of Economic Literature v37 n4, December 1999

Banerjee, Abhijit V. and Andrew F. Newman, Poverty, Incentives and Development, American Economic Review v84 n2, May 1994

Bertero, Elisabetta and Laura Rondi, Investment, Cash Flow and Managerial Discretion in StateOwned Firms, Evidence across soft and hard budget constraints, LSE Financial Markets Group Special Paper, n. 119, May 2000

Bigsten, Arne, Paul Collier, Stefan Dercon, Marcel Fafchamps, Bernard Gauthier, Jan Willem Gunning, Mans Soderbom, Abena Oduro, Remco Oostendorp, Cathy Patillo, Francis Teal, and Albert Zeufack, Credit Constraints in Manufacturing Enterprises in Africa, Centre for the Study of African Economies Working Paper Series 2000.24, September 2000.

Bond, Stephen, Julie Elston, Jacques Mairesse, and Benoît Mulkay, Financial Factors and Investment in Belgium, France, Germany, and the UK: A Comparison using Company Panel Data, NBER Working Paper Series 5900, National Bureau of Economic Research, Cambridge, Massachusetts, January 1997

Bond, Stephen and C. Meghir, Dynamic Investment Models and the firms financial policy, Review of Economic Studies, 61, 197-222, 1994

Branstetter, Lee G. and Robert C. Feenstra, Trade and Direct foreign investment in China:A Political Economy Approach, NBER Working Paper No. W7100, April, 1999

Fazzari, Steven M., R. Glenn Hubbard, and Bruce C. Petersen, Financing Constraints and Corporate Investment, Brookings Papers on Economic Activity (1988:1), 141-195.

-------------, Investment-Cash Flow Sensitivities are Useful: A Comment on Kaplan and Zingales, Quarterly Journal of Economics 115(2), May 2000, 695-706.

Feldstein, Martin, Aspects of Global Economic Integration:Outlook for the Future, NBER Working Paper 7899, September 2000

Gelos, Gaston R. and Alejandro M. Werner, Financial Liberalization, Credit Constraints, and Collateral:Investment in the Mexican Manufacturing Sector, IMF Working Paper, WP/99/25

Gilchrist, Simon and Charlie Himmelberg, Evidence on the Role of Cash Flow for Investment, Journal of Monetary Economics, 36, 541-572, 1995 
Gilchrist, Simon and Charles P. Himmelberg, Investment, Fundamentals and Finance, NBER Macro Annual 1998, Ben S. Bernanke and Julio J. Rotemberg eds., the MIT Press, Cambridge, 223-274

The Globecon Group Ltd., Active Bank Risk Management:enhancing investment \& credit portfolio performance, Burr Ridge, Illinois, Irwin Professional Publications, 1995

Harris, John R., Fabio Schiantarelli, and Miranda Siregar, The Effect of Financial Liberalization on the Capital Structure and Investment Decisions of Indonesian Manufacturing Establishments, The World Bank Economic Review, January, 1994

Harrison, Ann E., Productivity, Imperfect Competition and Trade Reform: Theory and Evidence, Journal of International Economics, v. 36, n1-2, February 1994

Harvard Institute for International Development and World Economic Forum, The Africa Competitiveness Report 1998, World Economic Forum, Geneva Switzerland, 1998

Hubbard, R. Glenn, Capital-Market Imperfections and Investment, Journal of Economic Literature, vol. XXXVI, pp. 193-225, March 1998

Jaramillo, Fidel, Fabio Schiantarelli and Andrew Weiss, Capital market imperfections before and after financial liberalization: An Euler equation approach to panel data for Ecuadorian firms, Journal of Development Economics, Vol. 51, Issue 2, December 1996

Kaplan, Steven N. and Luigi Zingales, Do Investment-Cash Flow Sensitivities Provde Useful Measures of Financing Constraints? Quarterly Journal of Economics, CXII(1997), 169215.

Love, Inessa, Financial Development and Financing Constraints: International Evidence from the Structural Investment Model, Ph.D. Dissertation, Columbia Business School, October 2000 .

Minton, Bernadette A. and Catherine Schrand, The impact of cash flow volatility on discretionary investment and the costs of debt and equity financing, Journal of Financial Economics v54, 1999

Patillo, Catherine, Risk, Financial Constraints and Equipment Investment in Ghana:A Firm-level Analysis Ch. 4 of Investment and Risk in Africa edited by Paul Collier and Catherine Patillo, St. Martin's Press, New York, New York, 2000

Ross, Stephen A., Randolph W. Westerfield, and Jeffrey Jaffe, Corporate Finance, $4^{\text {th }}$ edition, The Irwin Series in Finance, Chicago, IL, 1996

Tybout, James R., Credit Rationing and Investment Behavior in a Developing Country, Review of Economics and Statistics, Vol. 65, Issue 4 (Nov., 1983), 598-607 
The World Bank and Bastiaan A. den Tuinder, Ivory Coast The Challenge of Success, A World Bank Country Economic Report, The Johns Hopkins University Press, Baltimore, Maryland, 1978

Schiantarelli, Fabio, Financial Constraints and Investments: Methodological Issues and International Evidence, Oxford Review of Economic Policy 12, 70-89, 1996

Stiglitz, Joseph, The Role of International Financial Institutions in the Current Global Economy, Address to the Chicago Council on Foreign Relations, Chicago, February 27, 1998

United Sates Federal Research Division of the Library of Congress, Cote d'Ivoire a country study, Library of Congress, Washington, D.C., 1991

Whited, Toni, Liquidity Constraints, and Corporate Investment: Evidence from Panel Data, The Journal of Finance, Vol XLVII, No. 4, September 1992. 


\section{Table 1}

GMM Estimates of Augmented Euler Investment Equation to Test for Credit Constraints and Crowding Out

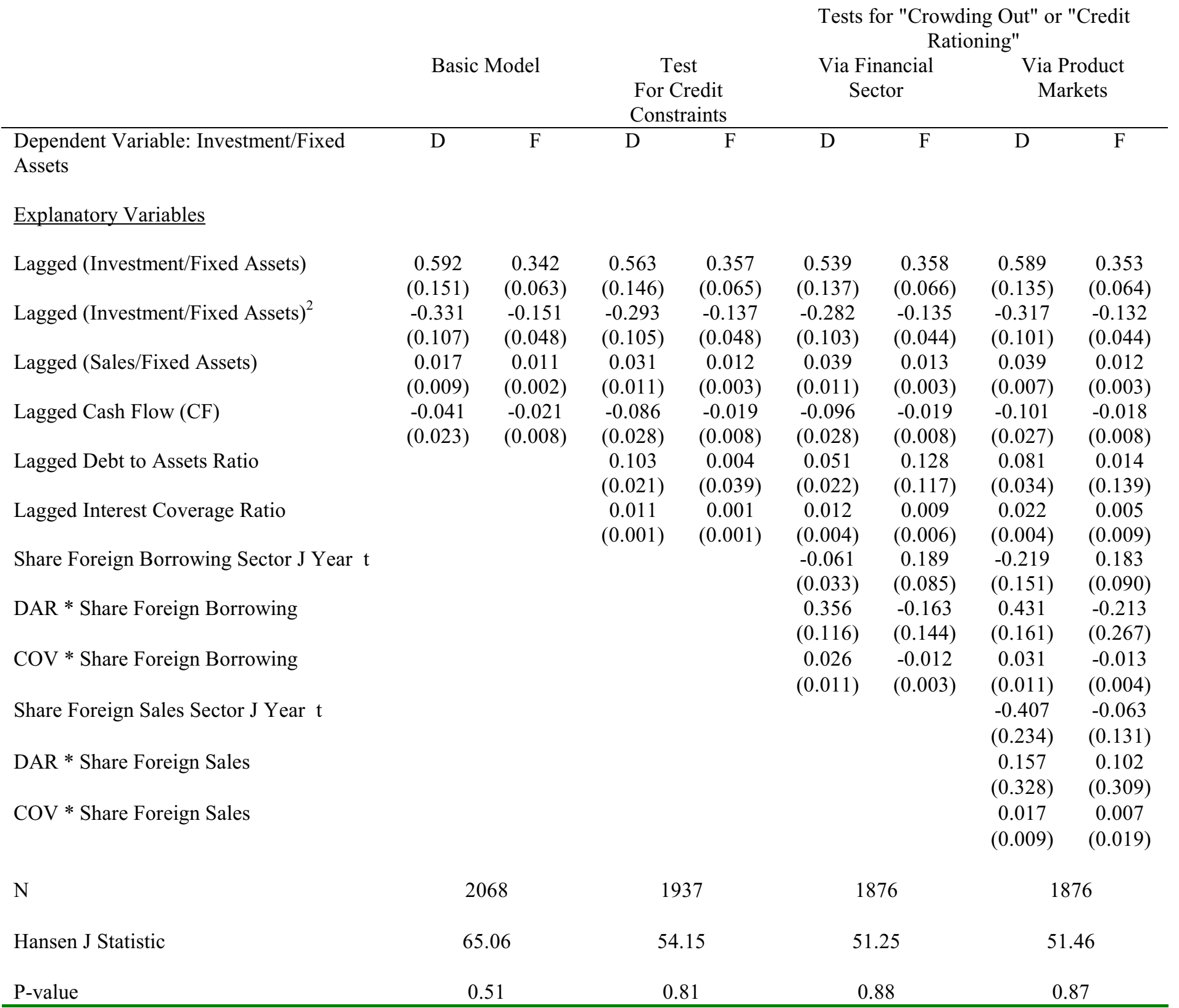

(1)The Helmert transformation is used to eliminate firm-level fixed effects. Instruments used are levels of all variables in the regression and sector dummies. (2) Standard errors in (). (3) In all specifications, domestic firms are those firms for which average foreign ownership over the life of the firm is less than or equal to $49 \%$. All other firms are classified as domestic. (4) Results are robust to outliers using the dfbeta criterion prior to estimation by GMM. 
Table 2

GMM Estimates of Augmented Euler Investment Equation to Test for Credit Constraints and Crowding Out Domestic Firms Broken down into State-Owned vs. Private Owned

Basic Model

$$
\text { Tests for "Crowding Out" or "Credit }
$$
Rationing"

\begin{tabular}{|c|c|c|c|c|c|c|c|c|}
\hline \multirow[b]{2}{*}{$\begin{array}{l}\text { Dependent Variable: Investment/Fixed } \\
\text { Assets }\end{array}$} & \multicolumn{2}{|c|}{ Basic Model } & \multicolumn{2}{|c|}{$\begin{array}{c}\text { Test } \\
\text { For Credit } \\
\text { Constraints }\end{array}$} & \multicolumn{2}{|c|}{$\begin{array}{l}\text { Via Financial } \\
\text { Sector }\end{array}$} & \multicolumn{2}{|c|}{$\begin{array}{l}\text { Via Product } \\
\text { Markets }\end{array}$} \\
\hline & $\mathrm{SOE}$ & Private & $\mathrm{SOE}$ & Private & $\mathrm{SOE}$ & Private & SOE & Private \\
\hline \multicolumn{9}{|l|}{$\underline{\text { Explanatory Variables }}$} \\
\hline Lagged (Investment/Fixed Assets) & $\begin{array}{c}1.591 \\
(0.859)\end{array}$ & $\begin{array}{c}0.495 \\
(0.161)\end{array}$ & $\begin{array}{c}0.358 \\
(0.392)\end{array}$ & $\begin{array}{c}0.539 \\
(0.168)\end{array}$ & $\begin{array}{c}0.748 \\
(0.292)\end{array}$ & $\begin{array}{c}0.481 \\
(0.153)\end{array}$ & $\begin{array}{c}0.748 \\
(0.258)\end{array}$ & $\begin{array}{c}0.495 \\
(0.162)\end{array}$ \\
\hline Lagged (Investment/Fixed Assets) ${ }^{2}$ & $\begin{array}{l}-1.179 \\
(0.709)\end{array}$ & $\begin{array}{l}-0.263 \\
(0.115)\end{array}$ & $\begin{array}{l}-0.094 \\
(0.202)\end{array}$ & $\begin{array}{l}-0.279 \\
(0.121)\end{array}$ & $\begin{array}{l}-0.397 \\
(0.202)\end{array}$ & $\begin{array}{l}-0.245 \\
(0.107)\end{array}$ & $\begin{array}{l}-0.497 \\
(0.225)\end{array}$ & $\begin{array}{l}-0.279 \\
(0.115)\end{array}$ \\
\hline Lagged (Sales/Fixed Assets) & $\begin{array}{c}0.037 \\
(0.025)\end{array}$ & $\begin{array}{c}0.005 \\
(0.001)\end{array}$ & $\begin{array}{c}0.059 \\
(0.020)\end{array}$ & $\begin{array}{c}0.009 \\
(0.002)\end{array}$ & $\begin{array}{c}0.038 \\
(0.019)\end{array}$ & $\begin{array}{c}0.037 \\
(0.014)\end{array}$ & $\begin{array}{c}0.023 \\
(0.021)\end{array}$ & $\begin{array}{c}0.009 \\
(0.003)\end{array}$ \\
\hline Lagged Cash Flow (CF) & $\begin{array}{l}-0.023 \\
(0.114)\end{array}$ & $\begin{array}{l}-0.011 \\
(0.003)\end{array}$ & $\begin{array}{l}-0.122 \\
(0.076)\end{array}$ & $\begin{array}{c}-0.021 \\
(0.008)\end{array}$ & $\begin{array}{c}0.037 \\
(0.104)\end{array}$ & $\begin{array}{l}-0.028 \\
(0.013)\end{array}$ & $\begin{array}{c}0.122 \\
(0.116)\end{array}$ & $\begin{array}{l}-0.021 \\
(0.007)\end{array}$ \\
\hline Lagged Debt to Assets Ratio & & & $\begin{array}{c}-0.027 \\
(0.118)\end{array}$ & $\begin{array}{c}0.116 \\
(0.019)\end{array}$ & $\begin{array}{c}-0.027 \\
(0.179)\end{array}$ & $\begin{array}{c}0.061 \\
(0.017)\end{array}$ & $\begin{array}{c}-0.082 \\
(0.183)\end{array}$ & $\begin{array}{c}0.064 \\
(0.011)\end{array}$ \\
\hline Lagged Interest Coverage Ratio & & & $\begin{array}{c}0.006 \\
(0.005)\end{array}$ & $\begin{array}{c}0.011 \\
(0.001)\end{array}$ & $\begin{array}{c}-0.006 \\
(0.005)\end{array}$ & $\begin{array}{c}0.014 \\
(0.005)\end{array}$ & $\begin{array}{c}-0.003 \\
(0.008)\end{array}$ & $\begin{array}{c}0.042 \\
(0.021)\end{array}$ \\
\hline Share Foreign Borrowing Sector J Year t & & & & & $\begin{array}{c}0.822 \\
(0.577)\end{array}$ & $\begin{array}{l}-0.016 \\
(0.009)\end{array}$ & $\begin{array}{c}0.018 \\
(0.799)\end{array}$ & $\begin{array}{c}-0.069 \\
(0.036)\end{array}$ \\
\hline DAR * Share Foreign Borrowing & & & & & $\begin{array}{c}0.422 \\
(0.514)\end{array}$ & $\begin{array}{c}0.361 \\
(0.121)\end{array}$ & $\begin{array}{c}-0.886 \\
(0.615)\end{array}$ & $\begin{array}{c}0.361 \\
(0.127)\end{array}$ \\
\hline $\mathrm{COV} *$ Share Foreign Borrowing & & & & & $\begin{array}{c}-0.026 \\
(0.141)\end{array}$ & $\begin{array}{c}0.017 \\
(0.007)\end{array}$ & $\begin{array}{c}0.114 \\
(0.115)\end{array}$ & $\begin{array}{c}0.086 \\
(0.021)\end{array}$ \\
\hline Share Foreign Sales Sector J Year t & & & & & & & $\begin{array}{c}0.822 \\
(0.741)\end{array}$ & $\begin{array}{c}-0.349 \\
(0.199)\end{array}$ \\
\hline DAR * Share Foreign Sales & & & & & & & $\begin{array}{c}-0.449 \\
(0.635)\end{array}$ & $\begin{array}{c}-0.477 \\
(0.430)\end{array}$ \\
\hline $\mathrm{COV} *$ Share Foreign Sales & & & & & & & $\begin{array}{c}-0.088 \\
(0.058)\end{array}$ & $\begin{array}{l}-0.196 \\
(0.157)\end{array}$ \\
\hline $\mathrm{N}$ & \multicolumn{2}{|c|}{2068} & \multicolumn{2}{|c|}{1937} & \multicolumn{2}{|c|}{1876} & \multicolumn{2}{|c|}{1876} \\
\hline Hansen J Statistic & \multicolumn{2}{|c|}{48.48} & \multicolumn{2}{|c|}{48.82} & \multicolumn{2}{|c|}{46.57} & \multicolumn{2}{|c|}{47.54} \\
\hline P-value & \multicolumn{2}{|c|}{0.93} & \multicolumn{2}{|c|}{0.92} & \multicolumn{2}{|c|}{0.95} & \multicolumn{2}{|c|}{0.94} \\
\hline
\end{tabular}

(1)The Helmert transformation is used to eliminate firm-level fixed effects. Instruments used are levels of all variables in the regression and sector dummies. (2) Standard errors in (). (3) In all specifications, domestic firms are those firms for which average foreign ownership over the life of the firm is less than or equal to $49 \%$. All other firms are classified as domestic. (4) Results are robust to outliers using the dfbeta criterion prior to estimation by GMM. 


\section{Table 3}

Why Would Domestic Firms Get Crowded Out? A Comparison of Firm Characteristics by Ownership

\begin{tabular}{|c|c|c|c|c|c|}
\hline Variable & $\mathrm{N}$ & $\begin{array}{c}\text { Mean } \\
\text { Domestic } \\
\text { SOE }\end{array}$ & $\begin{array}{c}\text { Mean } \\
\text { Domestic } \\
\text { Private }\end{array}$ & $\begin{array}{l}\text { Mean } \\
\text { Foreign }\end{array}$ & $\begin{array}{l}\text { t-statistic } \\
\text { for change } \\
\text { in mean }\end{array}$ \\
\hline \multicolumn{6}{|l|}{ A. Investment, cash flow and sales growth } \\
\hline $\mathrm{I}_{\mathrm{t}} / \mathrm{K}_{\mathrm{t}-1}$ & 2403 & 0.166 & 0.325 & 0.363 & 1.962 \\
\hline Cash Flow $\mathrm{t}_{\mathrm{t}-1}$ & 2403 & 0.254 & 0.421 & 0.417 & 0.454 \\
\hline Real Sales Growth ${ }_{t}$ & 2403 & 0.089 & 0.039 & 0.042 & 0.547 \\
\hline Real Capital Stock (millions of CFA) & 2403 & $1,579.0$ & 148.0 & 249.1 & 4.195 \\
\hline \multicolumn{6}{|l|}{ B. Debt Ratios and Growth ${ }^{2}$} \\
\hline$\overline{\text { Debt to Assets Ratio (DAR) }} \mathrm{t}_{\mathrm{t}}$ & 2403 & 0.427 & 0.269 & 0.271 & 0.736 \\
\hline Interest Coverage Ratio $(\mathrm{COV})_{\mathrm{t}}$ & 2403 & 0.858 & 0.419 & 0.373 & 2.018 \\
\hline Real Debt Growth & 2403 & 0.331 & 0.182 & 0.345 & 3.098 \\
\hline \multicolumn{6}{|l|}{ C.Profitability Ratios ${ }^{3}$} \\
\hline Profit Margin & 2251 & 0.099 & 0.044 & 0.047 & 0.886 \\
\hline Return on Assets & 2251 & 0.161 & 0.006 & 0.084 & 4.745 \\
\hline Asset Turnover & 2403 & 2.779 & 3.437 & 4.249 & 8.027 \\
\hline \multicolumn{6}{|l|}{ D. Firm Size } \\
\hline Sales (millions of CFA) & 2403 & 3,157 & 322 & 857 & 8.579 \\
\hline Number of employees & 2403 & 501 & 68 & 149 & 7.423 \\
\hline
\end{tabular}

(1)Results were obtained by regressing ratios on a dummy variable for ownership and a constant. T-statistic is for the difference in mean between private domestic and foreign firms. (2) Debt to assets ratio is the real value of outstanding debt divided by the real value of current assets and is meant to capture both a firm's demand for borrowing and (3) Profit margin is defined as the ratio of real profits to real sales, return on assets is defined as the ratio of real profits to real assets and asset turnover is defined as the ratio of real sales to real assets. 


\section{Table 4}

\begin{tabular}{|c|c|c|c|c|c|c|c|c|}
\hline \multicolumn{9}{|c|}{$\begin{array}{l}\text { GMM Estimates of Augmented Euler Investment Equation } \\
\text { Robustness Checks of Crowding Out Variable }\end{array}$} \\
\hline $\begin{array}{l}\text { Dependent Variable: Investment/Fixed } \\
\text { Assets } \\
\text { Explanatory Variables }\end{array}$ & $\mathrm{D}$ & $\mathrm{F}$ & $\mathrm{D}$ & $\mathrm{F}$ & $\mathrm{D}$ & $\mathrm{F}$ & $\mathrm{D}$ & $\mathrm{F}$ \\
\hline Lagged (Investment/Fixed Assets) & $\begin{array}{c}0.539 \\
(0.137)\end{array}$ & $\begin{array}{c}0.358 \\
(0.066)\end{array}$ & $\begin{array}{c}0.668 \\
(0.218)\end{array}$ & $\begin{array}{c}0.371 \\
(0.075)\end{array}$ & $\begin{array}{l}0.616 \\
(0.235)\end{array}$ & $\begin{array}{c}0.378 \\
(0.079)\end{array}$ & $\begin{array}{l}0.406 \\
(0.191)\end{array}$ & $\begin{array}{c}0.413 \\
(0.076)\end{array}$ \\
\hline Lagged (Investment/Fixed Assets) ${ }^{2}$ & $\begin{array}{l}-0.282 \\
(0.103)\end{array}$ & $\begin{array}{l}-0.135 \\
(0.044)\end{array}$ & $\begin{array}{l}-0.388 \\
(0.209)\end{array}$ & $\begin{array}{l}-0.133 \\
(0.056)\end{array}$ & $\begin{array}{l}-0.381 \\
(0.130)\end{array}$ & $\begin{array}{l}-0.133 \\
(0.059)\end{array}$ & $\begin{array}{l}-0.179 \\
(0.113)\end{array}$ & $\begin{array}{l}-0.168 \\
(0.049)\end{array}$ \\
\hline Lagged (Sales/Fixed Assets) & $\begin{array}{c}0.039 \\
(0.011)\end{array}$ & $\begin{array}{c}0.013 \\
(0.003)\end{array}$ & $\begin{array}{c}0.014 \\
(0.008)\end{array}$ & $\begin{array}{c}0.010 \\
(0.003)\end{array}$ & $\begin{array}{c}0.013 \\
(0.004)\end{array}$ & $\begin{array}{c}0.009 \\
(0.003)\end{array}$ & $\begin{array}{c}0.026 \\
(0.013)\end{array}$ & $\begin{array}{c}0.011 \\
(0.003)\end{array}$ \\
\hline Lagged Cash Flow (CF) & $\begin{array}{l}-0.096 \\
(0.028)\end{array}$ & $\begin{array}{l}-0.019 \\
(0.008)\end{array}$ & $\begin{array}{c}-0.058 \\
(0.016)\end{array}$ & $\begin{array}{l}-0.010 \\
(0.003)\end{array}$ & $\begin{array}{l}-0.027 \\
(0.012)\end{array}$ & $\begin{array}{c}-0.008 \\
(0.003)\end{array}$ & $\begin{array}{l}-0.074 \\
(0.034)\end{array}$ & $\begin{array}{l}-0.014 \\
(0.009)\end{array}$ \\
\hline Lagged Debt to Assets Ratio & $\begin{array}{c}0.051 \\
(0.022)\end{array}$ & $\begin{array}{c}0.128 \\
(0.117)\end{array}$ & $\begin{array}{c}0.099 \\
(0.039)\end{array}$ & $\begin{array}{l}-0.426 \\
(0.351)\end{array}$ & $\begin{array}{c}0.379 \\
(0.152)\end{array}$ & $\begin{array}{l}-0.801 \\
(0.558)\end{array}$ & $\begin{array}{c}0.356 \\
(0.172)\end{array}$ & $\begin{array}{l}-0.233 \\
(0.361)\end{array}$ \\
\hline Lagged Interest Coverage Ratio & $\begin{array}{c}0.012 \\
(0.004)\end{array}$ & $\begin{array}{c}0.009 \\
(0.006)\end{array}$ & $\begin{array}{c}0.038 \\
(0.016)\end{array}$ & $\begin{array}{c}0.022 \\
(0.028)\end{array}$ & $\begin{array}{c}0.048 \\
(0.019)\end{array}$ & $\begin{array}{c}0.039 \\
(0.035)\end{array}$ & $\begin{array}{c}0.026 \\
(0.012)\end{array}$ & $\begin{array}{l}-0.033 \\
(0.061)\end{array}$ \\
\hline Share Foreign Borrowing Sector J Year $t$ & $\begin{array}{l}-0.061 \\
(0.033)\end{array}$ & $\begin{array}{c}0.189 \\
(0.085)\end{array}$ & $\begin{array}{c}-0.085 \\
(0.044)\end{array}$ & $\begin{array}{l}-0.036 \\
(0.148)\end{array}$ & $\begin{array}{c}-0.053 \\
(0.015)\end{array}$ & $\begin{array}{c}0.017 \\
(0.011)\end{array}$ & $\begin{array}{l}-0.115 \\
(0.038)\end{array}$ & $\begin{array}{c}0.009 \\
(0.161)\end{array}$ \\
\hline DAR * Share Foreign Borrowing & $\begin{array}{c}0.356 \\
(0.116)\end{array}$ & $\begin{array}{l}-0.163 \\
(0.144)\end{array}$ & $\begin{array}{c}0.383 \\
(0.194)\end{array}$ & $\begin{array}{c}0.587 \\
(0.453)\end{array}$ & $\begin{array}{c}1.045 \\
(0.472)\end{array}$ & $\begin{array}{l}-0.774 \\
(0.588)\end{array}$ & $\begin{array}{c}0.797 \\
(0.328)\end{array}$ & $\begin{array}{c}0.319 \\
(0.510)\end{array}$ \\
\hline $\mathrm{COV} *$ Share Foreign Borrowing & $\begin{array}{c}0.026 \\
(0.011)\end{array}$ & $\begin{array}{l}-0.012 \\
(0.003)\end{array}$ & $\begin{array}{c}0.087 \\
(0.038)\end{array}$ & $\begin{array}{l}-0.033 \\
(0.042)\end{array}$ & $\begin{array}{c}0.114 \\
(0.049)\end{array}$ & $\begin{array}{l}-0.056 \\
(0.051)\end{array}$ & $\begin{array}{c}0.049 \\
(0.014)\end{array}$ & $\begin{array}{c}0.044 \\
(0.082)\end{array}$ \\
\hline DAR * Relative Firm Size Workers & & & $\begin{array}{c}0.011 \\
(0.008)\end{array}$ & $\begin{array}{c}0.002 \\
(0.002)\end{array}$ & & & & \\
\hline COV * Relative Firm Size Workers & & & $\begin{array}{l}-0.031 \\
(0.022)\end{array}$ & $\begin{array}{l}0.001 \\
(.001)\end{array}$ & & & & \\
\hline Relative Firm Size Workers & & & $\begin{array}{l}-0.021 \\
(.022)\end{array}$ & $\begin{array}{l}0.001 \\
(.009)\end{array}$ & & & & \\
\hline DAR * Relative Firm Size Sales & & & & & $\begin{array}{l}0.017 \\
(.012)\end{array}$ & $\begin{array}{l}0.003 \\
(.004)\end{array}$ & & \\
\hline $\mathrm{COV} *$ Relative Firm Size Sales & & & & & $\begin{array}{l}-0.045 \\
(.034)\end{array}$ & $\begin{array}{l}0.007 \\
(.006)\end{array}$ & & \\
\hline Relative Firm Size Sales & & & & & $\begin{array}{l}0.022 \\
(.033)\end{array}$ & $\begin{array}{l}-0.008 \\
(.004)\end{array}$ & & \\
\hline DAR * Relative Profitability & & & & & & & $\begin{array}{l}0.020 \\
(.018)\end{array}$ & $\begin{array}{l}-0.027 \\
(.011)\end{array}$ \\
\hline $\mathrm{COV} *$ Relative Profitability & & & & & & & $\begin{array}{l}0.043 \\
(.031)\end{array}$ & $\begin{array}{l}0.001 \\
(.012)\end{array}$ \\
\hline Relative Profitability & & & & & & & $\begin{array}{l}-0.007 \\
(.005)\end{array}$ & $\begin{array}{l}-0.014 \\
(.013)\end{array}$ \\
\hline $\mathrm{N}$ & & & & & & & & \\
\hline Hansen J Statistic & & & & & & & & \\
\hline P-value & & & & & & & & \\
\hline
\end{tabular}

(1)The Helmert transformation is used to eliminate firm-level fixed effects. Instruments used are levels of all variables in the regression and sector dummies. (2) Standard errors in (). (3) In all specifications, domestic firms are those firms for which average foreign ownership over the life of the firm is less than or equal to $49 \%$. All other firms are classified as domestic. (4) Results are robust to outliers using the dfbeta criterion prior to estimation by GMM. 
Table 5 - Contribution of DFI to Capital

\begin{tabular}{|c|c|c|c|c|c|}
\hline Year & $\begin{array}{l}\text { Foreign Tax } \\
\text { /Total Tax }\end{array}$ & $\begin{array}{l}\text { Foreign Tax } \\
\text { /Foreign Sales }\end{array}$ & $\begin{array}{l}\text { Total Foreign } \\
\text { Borrowing } \\
\text { (bn. Cfa francs) }\end{array}$ & $\begin{array}{l}\text { Total Foreign } \\
\text { Equity } \\
\text { (bn. cfa francs) }\end{array}$ & $\begin{array}{l}\text { Foreign } \\
\text { Equity/Foreign } \\
\text { Borrowing }\end{array}$ \\
\hline 75 & $79.03 \%$ & $17.63 \%$ & 44.00 & 26.70 & $60.68 \%$ \\
\hline 76 & $81.87 \%$ & $19.14 \%$ & 64.00 & 33.10 & $51.72 \%$ \\
\hline 77 & $78.27 \%$ & $23.48 \%$ & 79.70 & 33.20 & $41.66 \%$ \\
\hline 78 & $75.60 \%$ & $26.01 \%$ & 112.00 & 37.40 & $33.39 \%$ \\
\hline 79 & $75.10 \%$ & $27.62 \%$ & 136.00 & 42.60 & $31.32 \%$ \\
\hline 80 & $75.67 \%$ & $30.00 \%$ & 162.00 & 50.40 & $31.11 \%$ \\
\hline 81 & $74.72 \%$ & $31.46 \%$ & 169.00 & 52.80 & $31.24 \%$ \\
\hline 82 & $74.34 \%$ & $33.97 \%$ & 181.00 & 56.40 & $31.16 \%$ \\
\hline 83 & $72.00 \%$ & $34.43 \%$ & 208.00 & 59.40 & $28.56 \%$ \\
\hline 84 & $74.91 \%$ & $40.93 \%$ & 199.00 & 65.40 & $32.86 \%$ \\
\hline 85 & $74.52 \%$ & $42.19 \%$ & 195.00 & 61.10 & $31.33 \%$ \\
\hline 86 & $71.03 \%$ & $42.74 \%$ & 204.00 & 66.00 & $32.35 \%$ \\
\hline 87 & $65.63 \%$ & $39.44 \%$ & 185.00 & 63.70 & $34.43 \%$ \\
\hline
\end{tabular}




\section{Table A.1}

Origin of Long Term Borrowing by Foreign Firms in 1985 (millions of cfa francs)

\begin{tabular}{lccc}
\hline \hline Sector & $\begin{array}{c}\text { Total } \\
\text { Borrowing }\end{array}$ & $\begin{array}{c}\text { Amount } \\
\text { Borrowed } \\
\text { Abroad }^{\mathrm{a}}\end{array}$ & $\begin{array}{c}\text { Percent } \\
\text { Borrowed } \\
\text { Abroad }\end{array}$ \\
\hline Food & 15,315 & 2,031 & 13.26 \\
Textiles \& Clothing & 5,610 & 596 & 10.62 \\
Leather Products & 559 & 52 & 9.30 \\
Wood Products & 7,380 & 839 & 11.37 \\
Chemicals & 6,820 & 687 & 10.07 \\
Rubber \& Cement & 4,610 & 167 & 3.62 \\
Building Materials & 1,160 & 177 & 15.26 \\
Transportation Materials & 3,690 & 1,867 & 50.60 \\
Tools & 3,870 & 262 & 6.93 \\
Paper Products & 3,420 & 45 & 1.32 \\
\hline \hline
\end{tabular}




\section{Table A.2}

Ownership Structure by Sector

\begin{tabular}{|c|c|c|c|c|}
\hline Sector & No. Firms & $\begin{array}{c}\text { Domestic } \\
\text { Public }\end{array}$ & $\begin{array}{c}\text { Domestic } \\
\text { Private }\end{array}$ & Foreign \\
\hline Food - Coffee & 45 & $2.72 \%$ & $44.69 \%$ & $52.44 \%$ \\
\hline Food - Condiments & 20 & $16.14 \%$ & $14.40 \%$ & $69.46 \%$ \\
\hline Food - Beverages & 6 & $0 \%$ & $18.33 \%$ & $81.67 \%$ \\
\hline Food - Cooking Oils & 5 & $32.63 \%$ & $11.81 \%$ & $55.56 \%$ \\
\hline Food - Sugar & 9 & $8.45 \%$ & $12.32 \%$ & $79.22 \%$ \\
\hline Textiles \& Clothing & 38 & $11.15 \%$ & $17.08 \%$ & $71.60 \%$ \\
\hline Leather Products & 15 & $0 \%$ & $6.89 \%$ & $93.12 \%$ \\
\hline Wood Products & 60 & $0.28 \%$ & $25.89 \%$ & $73.49 \%$ \\
\hline Chemicals & 53 & $4.40 \%$ & $13.61 \%$ & $82.00 \%$ \\
\hline Rubber \& Cement & 6 & $20.42 \%$ & $19.31 \%$ & $60.27 \%$ \\
\hline Building Materials & 17 & $7.77 \%$ & $24.03 \%$ & $68.20 \%$ \\
\hline Transportation Materials \& Tools & 80 & $0.61 \%$ & $2.25 \%$ & $97.14 \%$ \\
\hline Paper Products & 45 & $8.70 \%$ & $24.16 \%$ & $67.14 \%$ \\
\hline Total & 399 & & & \\
\hline
\end{tabular}


Table A.3

Overall Composition of Debt by Ownership (1975 - 1987)

\begin{tabular}{lccc}
\hline \hline $\begin{array}{l}\text { Debt Type } \\
\text { Long-term Debt }\end{array}$ & $\begin{array}{c}\text { Domestic } \\
\text { Public }\end{array}$ & $\begin{array}{c}\text { Domestic } \\
\text { Private }\end{array}$ & Foreign \\
Short-term Debt & 0.47 & 0.39 & 0.29 \\
Of which: & 0.53 & 0.61 & 0.71 \\
Suppliers Credits & & & 0.28 \\
Bank Debt & 0.12 & 0.21 & 0.21 \\
Public Debt & 0.23 & 0.20 & 0.11 \\
\hline \hline
\end{tabular}


Table A.4

Descriptive Statistics of Variables Used in Analyses

\begin{tabular}{lccc}
\hline \hline Variable & $\begin{array}{c}\text { Number of } \\
\text { Observations }\end{array}$ & Mean & $\begin{array}{c}\text { Standard } \\
\text { Deviation }\end{array}$ \\
\hline Public Ownership & 2403 & 0.06 & 0.16 \\
Private Ownership & 2403 & 0.19 & 0.31 \\
Foreign Ownership & 2403 & 0.75 & 0.33 \\
Investment/Capital Stock & 2403 & 0.31 & 1.43 \\
Log of Real Sales & 2403 & 19.92 & 0.35 \\
Operating Cash Flow/Capital Stock & 2403 & 0.41 & 0.25 \\
Share of Foreign LT Borrowing in Sector j Year t & 2317 & 0.69 & 0.22 \\
Share of Foreign ST Borrowing in Sector (SC) & 2317 & 0.74 & 0.23 \\
Share of Foreign ST Borrowing in Sector (BC) & 2317 & 0.72 & 0.23 \\
Share of Foreign Public Borrowing in Sector & 2403 & 0.72 & 0.20 \\
Share of Foreign Sales & 2403 & 0.75 & \\
\hline \hline SC stand for suppliers credits and BC bank credits & & & \\
\hline
\end{tabular}

SC stand for suppliers credits and BC bank credits. 
Table A.5

\section{Borrowing \& Sales By Ownership}

\begin{tabular}{|c|c|c|c|c|c|c|}
\hline \multirow[t]{2}{*}{ Year } & \multicolumn{3}{|c|}{ Borrowing } & \multicolumn{3}{|c|}{ Sales } \\
\hline & Public/Total & Private/Total & Foreign/Total & Public/Total & Private/Total & Foreign/Total \\
\hline 1975 & $17.16 \%$ & $6.52 \%$ & $76.32 \%$ & $12.03 \%$ & $4.82 \%$ & $83.15 \%$ \\
\hline 1976 & $23.30 \%$ & $6.12 \%$ & $70.58 \%$ & $16.73 \%$ & $4.61 \%$ & $78.65 \%$ \\
\hline 1977 & $9.56 \%$ & $7.86 \%$ & $82.59 \%$ & $7.81 \%$ & $5.91 \%$ & $86.29 \%$ \\
\hline 1978 & $17.70 \%$ & $7.11 \%$ & $75.19 \%$ & $12.37 \%$ & $5.46 \%$ & $82.17 \%$ \\
\hline 1979 & $33.42 \%$ & $8.67 \%$ & $57.91 \%$ & $20.14 \%$ & $6.08 \%$ & $73.78 \%$ \\
\hline 1980 & $31.56 \%$ & $8.13 \%$ & $60.32 \%$ & $18.37 \%$ & $6.82 \%$ & $74.80 \%$ \\
\hline 1981 & $32.10 \%$ & $8.64 \%$ & $59.26 \%$ & $18.01 \%$ & $8.03 \%$ & $73.96 \%$ \\
\hline 1982 & $30.67 \%$ & $9.17 \%$ & $60.16 \%$ & $17.41 \%$ & $7.26 \%$ & $75.32 \%$ \\
\hline 1983 & $29.08 \%$ & $7.58 \%$ & $63.33 \%$ & $20.06 \%$ & $6.20 \%$ & $73.74 \%$ \\
\hline 1984 & $30.40 \%$ & $7.10 \%$ & $62.50 \%$ & $25.10 \%$ & $6.09 \%$ & $68.81 \%$ \\
\hline 1985 & $32.57 \%$ & $6.26 \%$ & $61.17 \%$ & $23.84 \%$ & $6.11 \%$ & $70.06 \%$ \\
\hline 1986 & $28.44 \%$ & $6.41 \%$ & $65.15 \%$ & $19.30 \%$ & $5.85 \%$ & $74.85 \%$ \\
\hline 1987 & $32.95 \%$ & $6.17 \%$ & $60.89 \%$ & $22.92 \%$ & $6.98 \%$ & $70.10 \%$ \\
\hline
\end{tabular}




\section{Table A.6}

GMM Estimates of Euler Investment Equation Based on Different Sample Splits

\begin{tabular}{|c|c|c|c|c|c|c|}
\hline \multirow{2}{*}{ Dependent Variable: Investment/Fixed Assets } & \multicolumn{2}{|c|}{ Ownership $^{4}$} & \multicolumn{2}{|c|}{$\operatorname{Size}^{5}$} & \multicolumn{2}{|c|}{ Profitability $^{5}$} \\
\hline & Domestic & foreign & small & large & low & high \\
\hline Lagged (Investment/Fixed Assets) & $\begin{array}{c}0.189 \\
(0.063)\end{array}$ & $\begin{array}{c}0.375 \\
(0.056)\end{array}$ & $\begin{array}{c}0.366 \\
(0.055)\end{array}$ & $\begin{array}{c}0.385 \\
(0.056)\end{array}$ & $\begin{array}{c}0.369 \\
(0.054)\end{array}$ & $\begin{array}{c}0.370 \\
(0.055)\end{array}$ \\
\hline Lagged (Investment/Fixed Assets) Squared & $\begin{array}{l}-0.081 \\
(0.057)\end{array}$ & $\begin{array}{l}-0.171 \\
(0.045)\end{array}$ & $\begin{array}{l}-0.162 \\
(0.044)\end{array}$ & $\begin{array}{l}-0.179 \\
(0.045)\end{array}$ & $\begin{array}{l}-0.159 \\
(0.043)\end{array}$ & $\begin{array}{l}-0.166 \\
(0.044)\end{array}$ \\
\hline Lagged (Sales/Fixed Assets) & $\begin{array}{c}0.013 \\
(0.004)\end{array}$ & $\begin{array}{c}0.011 \\
(0.002)\end{array}$ & $\begin{array}{c}0.012 \\
(0.002)\end{array}$ & $\begin{array}{c}0.011 \\
(0.002)\end{array}$ & $\begin{array}{c}0.014 \\
(0.003)\end{array}$ & $\begin{array}{c}0.011 \\
(0.002)\end{array}$ \\
\hline Lagged Cash Flow (CF) & $\begin{array}{l}-0.007 \\
(0.008)\end{array}$ & $\begin{array}{l}-0.021 \\
(0.008)\end{array}$ & $\begin{array}{l}-0.021 \\
(0.008)\end{array}$ & $\begin{array}{c}-0.021 \\
(0.007)\end{array}$ & $\begin{array}{l}-0.026 \\
(0.008)\end{array}$ & $\begin{array}{l}-0.019 \\
(0.008)\end{array}$ \\
\hline $\mathrm{N}$ & 383 & 1685 & 1034 & 1034 & 1034 & 1034 \\
\hline Hansen J Statistic & 66.17 & 50.73 & 51.05 & 50.55 & 55.33 & 50.78 \\
\hline P-value & 0.39 & 0.89 & 0.88 & 0.89 & 0.77 & 0.88 \\
\hline
\end{tabular}

(1) The Helmert transformation is used to eliminate firm-level fixed effects. Instruments used are levels of all variables in the regression and sector dummies. (2) Standard errors in (). (3) Results are robust to outliers using the dfbeta criterion prior to estimation by GMM. (4) Firms are defined as domestic if they have less than 49 percent foreign ownership and foreign otherwise. (5) Reported results are based on splitting the sample by mean sales (firm size) and mean profitability defined by the profit margin equal to real profits over real sales. Results for the bottom and top quartiles of each distribution are similar as are the results when we base firm size on the number of workers rather than sales. 
Table A.7

GMM Estimates of Augmented Euler Investment Equation to Test for Credit Constraints Based on Different Sample Splits

\begin{tabular}{lccccccc}
\hline Dependent Variable: Investment/Fixed Assets & \multicolumn{2}{c}{ Ownership $^{4}$} & \multicolumn{3}{c}{ Size $^{5}$} & \multicolumn{2}{c}{ Profitability } \\
Explanatory Variables & Domestic & foreign & small & large & low & high \\
Lagged (Investment/Fixed Assets) & & & & & & \\
& & & & & & \\
& 0.497 & 0.382 & 0.372 & 0.402 & 0.407 & 0.368 \\
Lagged (Investment/Fixed Assets) Squared & $(0.069)$ & $(0.058)$ & $(0.060)$ & $(0.062)$ & $(0.062)$ & $(0.060)$ \\
& -0.218 & -0.155 & -0.147 & -0.174 & -0.175 & -0.143 \\
& $(0.050)$ & $(0.045)$ & $(0.046)$ & $(0.048)$ & $(0.048)$ & $(0.046)$ \\
Lagged (Sales/Fixed Assets) & 0.016 & 0.013 & 0.013 & 0.013 & 0.015 & 0.012 \\
& $(0.003)$ & $(0.003)$ & $(0.003)$ & $(0.003)$ & $(0.003)$ & $(0.003)$ \\
Lagged Cash Flow (CF) & -0.025 & -0.024 & -0.022 & -0.023 & -0.027 & -0.020 \\
& $(0.008)$ & $(0.008)$ & $(0.008)$ & $(0.009)$ & $(0.009)$ & $(0.009)$ \\
Lagged Debt to Assets Ratio & 0.534 & -0.014 & 0.019 & -0.021 & -0.013 & -0.020 \\
& $(0.079)$ & $(0.034)$ & $(0.029)$ & $(0.047)$ & $(0.037)$ & $(0.037)$ \\
Lagged Interest Coverage Ratio & & & & & & \\
& 0.075 & 0.001 & 0.007 & 0.008 & 0.009 & 0.007 \\
N & $(0.011)$ & $(0.002)$ & $(0.007)$ & $(0.008)$ & $(0.008)$ & $(0.007)$ \\
Hansen J Statistic & 359 & 1586 & 972 & 973 & 972 & 973 \\
P-value & & & & & & \\
\hline \hline
\end{tabular}

(1) The Helmert transformation is used to eliminate firm-level fixed effects. Instruments used are levels of all variables in the regression and sector dummies. (2) Standard errors in (). (3) Results are robust to outliers using the dfbeta criterion prior to estimation by GMM. (4) Firms are defined as domestic if they have less than 49 percent foreign ownership and foreign otherwise. (5) Reported results are based on splitting the sample by mean sales (firm size) and mean profitability defined by the profit margin equal to real profits over real sales. Results for the bottom and top quartiles of each distribution are similar as are the results when we base firm size on the number of workers rather than sales. 